\title{
Introduction
}

\section{Anthropology and knowledge production in a 'minefield'}

\author{
Andréa Zhouri \\ Departamento de Antropologia e Arqueologia, Universidade Federal de Minas Gerais, \\ Belo Horizonte, MG, Brasil
}

In 2003, when Chris Ballard and Glenn Banks updated - and upgraded - Ricardo Godoy's call for a systematization of an Anthropology of Mining (1985), they simultaneously warned: "mining is no ethnographic playground". Focused mainly in situations across the Asia-Pacific region, the review questioned the often monolithic "characterizations of state, corporate, and community forms of agency" and charted the debate among anthropologists involved in mining about the appropriate terms of their engagement - as consultants, researchers and advocates. Differently from the context analyzed by Godoy in the mid-1980s, the authors emphasized the novel and complex scope of mining activities, particularly the interplay of actors involved in large-scale hard-rock mines in the new millennium, ranging from local to global players: that is, indigenous peoples, local communities, state agencies, transnational corporations, national and transnational NGOs, social and environmental movements, international institutions, among others. Each of these actors has a different agenda, scope of actions and quantum of power at the mining sites. Ballard and Banks, drawing on Gedicks' (1993) "resource wars", ${ }^{1}$ pointed out the context of conflict typical of mining settings and the necessary considerations of the position of Anthropologists within these.

Such a warning is still relevant and reverberates in a rather more diverse and complex manner today, considering the current forms of neoextractivisms, which interlace high technology, the international division of labor and capital, the advances over new frontiers and, above all, the aggravation of mining's spillage effects (Gudynas 2016)2. Presently, the contexts and dynamics involving "resource wars" configure the emergence of different levels of institutional changes, such as the dismantlement of environmental regulations and norms that asserted the territorial rights of indigenous peoples which were firmly established in countries of Latin America since the 1980 and 1990s. This is relevant to bear in mind, since the scenario of environmental and indigenous rights regulations emphasized by Ballard and Banks in 2003

\footnotetext{
1 Gedicks' book presents different situations of conflict uniting the struggles of indigenous groups to environmentalists in various parts of the world - USA, Canada, Ecuador, Malaysia - opposing mining and other industrial projects which threatened their territories. Ballard and Banks highlight that conflicts in the Asia-Pacific region range from ideological opposition to armed disputes with loss of lives, livelihoods and environments (2003, p. 289).

2 Gudynas (2016, p. 26) explains the distinction between the term extractivism as referred to Brazilian traditional collective modes of appropriation of natural resources, such as of the rubber tappers' extractive reserves in the Amazon, and a plurality of extractivisms as particular types of appropriation of natural resources characterized by high and/or intensive volumes extracted, which are mostly directed to the exportation as raw materials, without or with limited industrial processing. By spillage effects - effectos derrame - of such extractivisms, the author means "the conditions and transformations generated beyond a particular project, the site where it is located and the policies that make it possible. The effects are observed, for instance, when changes of environmental rules and regulations affect the entire environmental policy of a state. Hence, the push of extractivisms spills consequences to the rest of a country, with changes in public policies, functioning of the economy, understandings of justice and democracy, and concepts of Nature" (Gudynas, 2016, p. 28, my translation from the original in Spanish).
} 
was different from the context of the 1980 os analyzed by Godoy, and has been rapidly changing. Nowadays, the setback in regulation has been accompanied by various forms of violence that go hand-in-hand with processes of de-politization and the criminalization of affected persons, subjects and movements engaged in resistance and critical researchers. ${ }^{3}$

"Commodities consensus" is the term used by Svampa (2013) to characterize the entry of Latin America in this new economic and political-ideological order sustained by the international boom of low prices of raw materials and consumer goods demanded by developed countries and emerging powers. Zhouri, Bolados and Castro (2016) call attention to a complex process of "violence of affectations" set in motion by neoextractivist practices as a corollary to such consensus. That process comprises a series of intertwined dynamics which is defined elsewhere, by world markets, but find material expression in the territories. Fundamentally, the "violence of affectations" encompasses expropriation, destruction of ecosystems, disruption of local and regional economies, as well as the annihilation of territorialized ways of living, being, knowing and doing (Zhouri and Valencio 2014). The affectations to the environment and to community-based ways of living are also perceived in the violation of norms - constructed with agreements at national and international levels - and in the distortion of political participative mechanisms consolidated in post-dictatorship regimes in Latin American countries. In addition to this conjunction of material and symbolic violence which are intrinsic to the expansion of mining frontiers in the continent today, there are other associated modalities of epistemic (Rigotto, Zhouri et al., this volume), racial and gender biased violence. These processes combined constitute a context typical of coloniality of power and knowledge (Quijano 2005; Mignolo 2003). What are the challenges for Anthropology and the ethnographic researcher in such 'minefield'?

As noted by Zhouri \& Oliveira (2012), large-scale projects, such as the case of mining, constitute a conflict arena involving locals, state sectors and entrepreneurial groups and researchers from different backgrounds and in various positions and scales. Within this context, anthropologists have increasingly been required to act as experts, consultants and mediators by different groups, including state institutions, private companies, financial bodies and social movements. These processes not only expand the professional market of anthropology, but also multiply the ethical, moral, theoretic and methodological challenges placed by the conditions of production of ethnographic knowledge. In such contexts, where asymmetrical power positions characterize social relations, and violations of basic human rights are not infrequent, the often-attempted "external position" of anthropologists is constantly questioned. In this sense, as emphasized by the authors, rather than participant observation, the participation required is considered as a "situated view in which anthropological discourse is always influenced by specific production conditions associated with the effects of relations of place" (Zhouri \& Oliveira 2012, p. 203), since positions in social space configure enunciative places in which certain constraints and potentialities become inserted in discourses.

Therefore, "expert opinions, studies and reports, as modalities of anthropological discourse, are texts/ scripts produced and appropriated through correlations of forces" (Zhouri \& Oliveira 2012, p. 204). In this ethnographic minefield, anthropological knowledge production requires reflexivity and responsibility, as this production generates connections and interferences in social processes. The management of conflict not rarely represents 'pacification' as suppressing of dissent (Zhouri 2015) through a series of technologies of governance that stage participation (Santos et al., this volume) while producing effects of silencing and

3 According to the latest report published by the Land Pastoral Comission (CPT), Conflitos no Campo 2016", 43,6\% of the 172 cases of water conflicts in Brazil during 2016 occured in the states of Minas Gerais and Espírito Santo. More than $50 \%$ of the total are connected to conflicts in mining projects, followed by 23,26\% which are related to hydroelectric dams (CPT, 2017, p.129-130). In addition, eleven community leaders, considered representatives of mining-affected people in five different regions of Minas Gerais, are under official protection (O Tempo, July 10, 2017, available in http://www.otempo.com.br/capa/economia/ conflitos-de-minera\% $\mathrm{C}_{3} \% \mathrm{~A} 7 \% \mathrm{C}_{3} \% \mathrm{~A}_{3} 0$-levam-11-a-programas-de-prote\% $\mathrm{C}_{3} \% \mathrm{~A} 7 \% \mathrm{C}_{3} \% \mathrm{~A}_{30} \mathrm{O}-1.1495202$. Access in July 31, 2017. 
acceptance. The global environmental governance package (Zhouri 2015) is thus indigenized, immersed in a global-local coalition of power that subsumes local and expert knowledges. The contributions in this dossier intend to instigate debate over such issues, fostering a new research agenda on those matters while presenting conflict situations related to large-scale mining in Brazil, as well a case of artisanal mining in Colombia.

Interestingly, for many years Brazil has been a country overlooked in most studies and anthropological reviews concerned with mining. This void may be related to the attention centered in supposedly more traditional mining countries in Latin America, particularly those located in the Andes region (see Damonte \& Castillo 2010; Alimonda 2011). However, it also may due to the fact that other conventional, and yet globalized, forms of environmental concerns have mobilized the research agenda about the country, like the interest in the ethnology of indigenous peoples, the topic of the Amazon rainforest and the various and interconnected driving forces of its deforestation: cattle ranching, timber industry, hydroelectric dams. In any case, the absence of anthropological interest in the topic of mining is surprising, given several centuries of extractivist activities in the state of Minas Gerais, as well as ore exploration operations in the Amazon since the mid-twentieth century, principally during the civil-military dictatorship that coincides with the international mining boom in the 1970 and 1980 s. $^{4}$

At any rate, the new wave of extractivism in Brazil and in Latin America, particularly between 2000 and 2011, is associated with a widespread process of re-primarization of the economy in the continent. Characterized by the primacy of commodity exportation in order to meet international market demands, this process represented, in reality, a subordinated position of Latin American countries within the global economy. It began with incentives to international investments promoted by neoliberal governments by means of reforms oriented to liberalize the mining sector. However, 'progressive' governments have also maintained this process, a dynamic identified as the above-mentioned commodities consensus (Svampa 2013) within the neo-extractivist model (Gudynas 2016). Mining companies, particularly in the case of iron ore, intensified their activities in order to increase the scale of production at the same time as reducing fixed costs (Hoyle 2015). This process gave rise to new "sacrificial zones", that is, new complex economic frontiers around mining that voraciously advanced over the territories of indigenous peoples and traditional communities.

The effects of different types of extractivism, especially large-scale mining, are visible far beyond the social and environmental impacts most often identified in the sites of extraction themselves. The "spillage effects" of mining, according to Gudynas (2016), can be observed farther: in institutions, governments, other facets of the economy and law systems and regulations, and furthermore, in variable scales and levels which are intertwined and still open to investigation. As some of the studies in this volume demonstrate, large-scale mining must be researched not only at the extraction and processing sites, but also in relation to infrastructure of energy and transportation that it requires, such as railroads, water pipelines and ports (see Santos et al; Antunes Junior \& Pantoja da Silva, in this volume; and Losekann 2016).

Since 2011, some countries in Latin America have experienced a decline in the international demand for minerals. Between 2011 and 2014, the volume of mining exports in Brazil dropped from US $\$ 44.2$ billion to US $\$ 28.4$ billion (International Trade Center 2016). Considering iron ore, copper and aluminium, the three major export minerals from Brazil, prices per ton declined $41 \%, 20 \%$ and $20 \%$, respectively (World Bank 2016). Among the effects are the decrease in taxes usually paid to mining municipalities to compensate for environmental damages, the increase in threats of disasters and work-related accidents, curtailment of preventive actions and environmental control of projects.

4 For a concise review of mining history and projects in the Amazon, see Nunes Coelho (2016). 
The geographies of transnational corporations and the state reveal strategies to monopolize and privatize common environments in the territories of indigenous groups and traditional communities, configuring major pressure upon forests, rivers, land and subsoil. The incursion into traditionally occupied land has incited conflicts in Brazil and other countries in the continent. Many rural communities have already been destroyed, as in the case of the Rio Doce disaster in Southeast Brazil (articles in the first part of this volume).

The collapse of the tailings dam owned by Samarco, a joint venture of two global mining titans, Vale and BHP Billiton, in November 2015, promoted the biggest mining disaster (in volume of spilled tailings) in Latin America and is iconic, in many respects, of the current economic, political and institutional context subject to analyses. There were nineteen immediate deaths and thousands of people are still displaced, facing loss of homes, land, crops and animals. They were forced to live in rented houses in the city, tied up in endless negotiations, kept waiting for resettlement, uncertain about their future, and outraged with the impunity of corporate and state collusion (see Zhouri et al. and Losekann, in this volume). Suddenly, dozens of cities had problems with water supplies, and rural and fishery villages were buried by the mineral waste that extended over $600 \mathrm{~km}$ in length, until the Atlantic Ocean. It is known that there were failures in the process of oversight and the monitoring of the dam, as discussed by Santos \& Milanez, in this volume.

Notwithstanding the disaster, politicians in the state of Minas Gerais moved quickly in passing a law that eases environmental impact assessment procedures to accelerate analysis and approval of large-scale mining projects. A similar process occurred in the Brazilian Senate, in which a Constitutional Amendment, first introduced in 2012, was passed in early 2016. In practice, this represents the dismantlement of the systems of norms and regulations that sustained obligatory environment impact assessment (see comments in Zhouri et al.; Santos \& Milanez and Acselrad, this volume), and calls for ethnographic studies about state practices and the construction of legalities, illegalities and 'alegalities' (Santos et al., this volume).

Disasters, relaxation of norms, and institutional setbacks place into question the very notion of democracy not only in Brazil, but in Latin America at large, conforming one of the "spillage effects" of mining. In Colombia, changes in environmental legislation have created the so-called "licencias expressas", as well as the "Paquetes ambientales" in Peru, whereas in Bolívia, new decrees allow the entry of the oil industry in protected areas. Hence, disasters of mining in the continent multiply, inasmuch as spaces of politics are transformed into instances of judicialization and criminalization of affected people and leaders of resistance movements, who struggle in defense of their territories and ways of life.

The violence of these forms of appropriation of the place of others, and their submission to diverse modes of threats - the extreme events of social and environmental disasters and their "spillage effects" obliterate differences, diversities, collective identities and choices.

In the face of such a grim scenario, indigenous peoples, fisherman, peasantry, Afro-descendants and others have mobilized themselves. They have contested the attack over their territories, the plunder of their natural resources, the invasion of corporate agents legitimized by state power and their prioritizing commodities export as basis for development. The critical experiences that depict the multiple processes of the "violence of affections" promoted by large-scale mining give rise to contexts of struggles and resistances that weave together distinct trajectories of activists, affected peoples, militants and researchers (see Rigotto and Acselrad, in this volume; Zhouri, Generoso and Corujo 2016). The understanding of such processes requires more investments in anthropological research, since Anthropology has traditionally contributed to the knowledge of territory as a place of culture and resistance. Furthermore, the discipline has been challenged to analyze globalizing processes and practice multi-sited ethnographies (Markus 1995). Along these lines, ethnographies of the state - as well as of corporations - can also help shed light on the construction and practices intended to control territories and manage conflict and dissent. 
On the other hand, these power strategies encounter responses by subjects and movements committed to values associated with ideas of autonomy, rights, identity, buen viver and others, collectively advanced, as ways to design alternative futures.

Large-scale extractivism is a topic that has mobilized the research agenda of scholars in multiple fields of knowledge. Anthropological research on mining and its effects on indigenous peoples and local communities has been a topic of classic ethnographies, like June Nash's We eat the mines and the mines eat us (1979), based on investigation in Bolivia, and Michael Taussig's The Devil and commodity fetishism in Latin America (1980). In Brazil, however, mining appears in occasional studies, mainly at the interface of Anthropology and development. A more consistent approach has connected development and indigenous peoples, or even Anthropology and hydroelectric dams rather than mining as a proper research field. Hence, this volume has a double purpose: on the one hand, it intends to unveil a field still open to scrutiny and, on the other hand, communicate to a wider international constituency the specificities of mining in Brazil and the research that has been carried out by Anthropologists in interaction with researchers from different areas of knowledge, including sociology, geography, engineering, political science and medicine. Indeed, mining requires an interdisciplinary approach, and Anthropology has a great deal to gain by interacting with other disciplines in order to understand the various processes, institutions and actors mobilized in the 'minefield'.

Mining, violence and resistance: contemporary themes for anthropological research in Brazil, is an invited issue of Vibrant - the Journal of Virtual Brazilian Anthropology. The articles in this volume were presented by scholars in different events organized by the Brazilian Anthropological Association (ABA) during 2016. Among those are the Special Symposium "Mining, social suffering and resistance in the context of Brazil and Latin America", held at the zoth Brazilian Anthropological Meeting (3oa. RBA), in João Pessoa, Paraíba, August 3-6; and the panel "Mariana, the story of a disaster: mining, social suffering and resistance", part of the $40^{\text {th }}$ Congress of ANPOCS, October 24-28.

This dossier is organized into two parts, each with four articles. The first part is entitled The Samarco mining disaster - affectations, resistance, policies. It brings together different analyses of the Rio Doce mining disaster that occurred in Brazil, in November 2015. The authors are researchers with experience in the topic of iron ore mining projects and whose research laboratories have followed the case of the disaster from its very beginning. Zhouri, Oliveira, Zucarelli and Vasconcelos, researchers of the Group of Environmental Studies of the Federal University of Minas Gerais (GESTA-UFMG), present an Anthropology of state practices and their effects upon 'affected people'. From that perspective, they examine the struggle between the objectification imposed by the policies of affectation and the political subjectivation of actors compulsorily brought to contentious settings over the control of their own destiny. The fetishism of numbers is questioned when the authors analyze the methodological instrument proposed by corporations to identify the universe of affected people, thus producing effects of inclusion and exclusion. The analysis of social suffering produced by the policies of affectations in Minas Gerais reveals affinities with the approach advanced by political scientist Cristiana Losekann in her research conducted within ORGANON - Center for Study, Research and Extension in Social Mobilization - of the Federal University of Espírito Santo (UFES). Losekann focuses on affected people in the 'other extreme continuum' of the disaster, that is, on the Atlantic coast, Espírito Santo State, located some $600 \mathrm{~km}$ further from the disaster epicenter. Based on fieldwork and in meetings with affected people, Losekann describes processes of mobilization which involve various actors and interactions marked by emotions and by the creation of affective bonds. Drawing on a culturalist framework of social movement studies, the article highlights the emotional mechanisms in play in the construction of collective action, in particular, claims for justice. 
Rodrigo Santos and Bruno Milanez, researchers of PoEMAS - Politics, Economics, Mining, Environment and Society - linked to the Federal Universities of Rio de Janeiro and Juiz de Fora (UFRJ and UFJF), present an interpretation of the relations between state, market and civil society in the context of the disaster and changes of environmental regulation of the mining industry in Brazil. They explore the novel roles and relations between state and corporations with regard to environmental dimensions, revealing the selective exclusion of civil society from the process. Based on document analysis and fieldwork, the authors analyze regulatory forms related to environmental licensing and monitoring of Samarco's operations, as well as mechanisms of management of impacts of the disaster in the Rio Doce Basin. They conclude that a blend of weak and private regulatory standards (self-regulation) has been established, adding corporate forms of private and public regulation to the process of institutional dismantlement in course in Brazil. Henri Acselrad, researcher of ETTERN - State, Work, Territory and Nature - laboratory of the Federal University of Rio de Janeiro (UFRJ), in his "genealogy of the disaster", identifies it as the expression of political failure in public control of private interests. Three specific issues are presented for further investigation: the operation of an "organized class irresponsibility", the systematic dis-consideration of alerts brought forth by citizens or groups pledged to the public interest, and the limits to the exercise of academic freedom in the field of environmental impact assessment procedures.

The second part of the dossier is entitled Violence, resistance and knowledge production. Ana Flávia Moreira Santos, researcher of GESTA-UFMG, in co-authorship with Luciana Ferreira and Vinicius Penna, analyzes rituals performed within the environmental impact assessment procedures of the iron ore Minas-Rio project, a venture owned by the Anglo American company. Their study is based on a long-term ethnography of meetings, actions and initiatives of both state actors and affected peoples. The Minas-Rio Project is a mining complex composed of mine - pipeline - port, which extends over $500 \mathrm{Km}$, from the hinterlands of Minas Gerais to the coastal areas of Rio de Janeiro. Violation of human rights, as such the right to information and the right to water, has often been denounced during the history of this project, including in international forums, like the United Nations. Through an ethnography of the political rituals performed in the institutional participative scenes, the authors discuss how mechanisms used to relax environmental norms were articulated throughout the process, generating strategies which allowed the operation of the project despite the lack of knowledge about - and acknowledgment of - the affected communities. Incidentally, the theme of knowledge production in relation to environmental conflicts is the main topic of Raquel Rigotto's contribution. Researcher of TRAMAS - Labor, Environment and Health - at the Federal University of Ceará (UFC), she focuses on the establishment of an environmental field when prospecting of uranium and phosphate in the Sertão Central (Central Hinterland) of Ceará, Northeast Brazil, was announced. The author, a medical doctor and sociologist, describes several ways of acting, the modus faciendi, that update and territorialize epistemicide and cognitive injustices in the context of neoextractivism. On the other hand, she highlights that the subjects affected engaged themselves in fruitful processes of knowledge construction in order to defend themselves from threats to their territories and ways of life. At the end, drawing on a "perspective of a science oriented by activism", Rigotto addresses the interfaces of such processes with the engagement of researchers with local subjects for a common, shared production of knowledge.

Horácio Antunes de Sant'Ana Junior and Elio de Jesus Pantoja Alves, both of GEDDMA - Group of Studies on Modernity, Development and Environment - at the Federal University of Maranhão (UFMA), analyze the "spillage effects" of iron ore mining in Carajás - an extraction site located in Pará, Eastern Amazon region - alongside the Estrada de Ferro Carajás (Carajás Railroad). Their focus is on the port city of São Luís do Maranhão, located in the Northeast Brazil. The authors consider the interrelations between mining, transport and exportation of iron ore, infrastructure projects, factories, extensive cattle farming 
and monoculture, and lumber exploitation as combined factors that damage the landscape of the Eastern Amazon region and threaten the local traditional way of life. Drawing on the concept of "spillage effects" of mining, the authors discuss environmental conflicts in São Luis around demands for an Extractive Reserve, ways to guarantee control over the territory, debates on urban legislation and opposition to the building of port terminals. Last, but not least, Eduardo Restrepo's contribution focuses on Colombia rather than Brazil. As an anthropologist of the Pontificia Universidad Javeriana de Bogota, Restrepo participated in the symposium about mining, organized during the 3oth Meeting of the Brazilian Anthropology Association, and contributed with the interesting discussion about artisanal mining in the North of Cauca, Colombia. Based on historical and anthropological data, he analyzes the process of dispossession promoted by illegal mining. The article examines processes of settlement of Afro-descendants in Cauca since colonial times and their traditional ways of mining interconnected to other economic activities. The text then provides a cartography of conflicts originated by the recent arrival of foreign miners, most of whom associated with illegal armed groups. The conflict between these newcomers and groups within the traditional black communities organized in defense of their threatened territories, is explored.

Finally, it is interesting to note that the articles assembled in this dossier have several features in common: political ecology is a common ground, in the sense that the studies are concerned with conflicts and power relations that characterize the interactions between social groups and the environment. The theme of inequality cuts across most of the articles, be it with regard to unequal access to and distribution of, nature, as well as threats related to mining; or in the sense of access to knowledge and political spheres of decision-making. Another aspect to emphasize is that most of the contributions are based on field experiences. This is an element dear to Anthropology as a discipline which has traditionally placed fieldwork at the heart of ethnography. Furthermore, researchers engaged in the study of mining have also positioned themselves in this field, questioning the role of science as discourses of truth, and particularly the universities, as "knowledge corporations" (Bastin and Morris 2003, p. 79) at the service of the reproduction of power, especially in a country marked by inequality, like Brazil. We hope that this contribution provides insights for further anthropological research on mining in Brazil and that international scholars and different actors critically engaged with the issue of mining may benefit from the experiences shared by Brazilian researchers in this volume.

English review: Franklin Rothman

\section{References}

ALIMONDA, H. 2011. La naturaleza colonizada: ecologia política y minería en America Latina. Buenos Aires: CLACSO/Ediciones Ciccus. pp. 334.

BALLARD, C.; Banks, G. 2003. "Resource wars: the anthropology of mining”. Annu. Rev. Anthropol., 32: 287-313.

BASTIN, Rohan; MORRIS, Barry. 2003. "Introduction”. Forum - Expert Knowledge: first world peoples, consultancy and anthropology. Social Analysis, 47(1): 77-83.

BEBBINGTON, A. 2011. Minería, movimientos sociales y respuestas campesinas: una ecología política de transformaciones territoriales. Lima: Instituto de Estudios Peruanos.

CPT - Comissão Pastoral da Terra. 2017. Conflitos no Campo 2016. Goiânia: CPT Nacional. pp. 232. 
DAMONTE, G.; CASTILLO, G. 2010. "Presentación: una mirada antropológica a las industrias extractivas en los Andes". Anthropologica/Año XXVIII, 28(Suplemento 1): 5-19.

GEDICKS, A. 1993. The new resource wars: native and environmental struggles against environmental corporations. Boston, MA: South End.

GODOY, R. 1985. "Mining: anthropological perspectives". Annu. Rev. Anthropol., 14: 199-217.

GUDYNAS, E. 2016. "Extractivismos en America der Sur: conceptos y sus efectos derrame”. In: A. Zhouri, P. Bolados, E. Castro (eds.), Mineração na America do Sul: neoextrativismo e lutas territoriais. São Paulo: Ed. Annablume. pp. 23-43.

HOYLE, R. 2015. "Titãs do minério de ferro tiram pequenos concorrentes do mercado". The Wall Street Journal. Available in: https:/|www.wsj.com/articles/titas-do-minerio-de-ferro-tiram-pequenosconcorrentes-do-mercado-1437624258. Access in August 15, 2015.

INTERNATIONAL TRADE CENTER. 2016. Trade map: trade statistics for international business development. Available in: http://www.trademap.org. Access in 19 July.

LOSEKANN, C. 2016. "O neoextrativismo visto através dos megaempreendimentos de infraestrutura: as zonas de sacríficios no Espírito Santo, Brasil”. In: A. Zhouri, P. Bolados, E. Castro (eds.), Mineração na América do Sul: neoextrativismo e lutas territoriais. São Paulo: Ed. Annablume. pp. 231-253.

MARKUS, G. 1995. "Ethnography in/of the world system: the emergence of multi-sited ethnography”. Annu. Rev. Anthropol., 24: 95-117.

MIGNOLO, W. 2003. “Os esplendores e as misérias da 'ciência': colonialidade, geopolítica do conhecimento e pluri-versalidade epistémica”. In: Boaventura Sousa Santos (org.), Conhecimento prudente para uma vida decente. São Paulo: Ed. Cortez. pp. 667-709.

NASH, J. 1979. We eat the mines and the mines eat us: dependency and exploitation in Bolivian tin mines. New York: Columbia Univ. Press.

NUNES COELHO, M. C. 2016. "Balanço do extrativismo (industrial e artesanal) e da estruturação regional na Amazônia oriental no período de 1970 a 2014". In: A. Zhouri, P. Bolados, E. Castro (eds.), Mineração na América do Sul: neoextrativismo e lutas territoriais. São Paulo: Ed. Annablume. pp. 133-153.

QUIJANO, A. 2005. “Colonialidade do poder, eurocentrismo e América Latina”. In: Edgardo Lander (ed.), A colonialidade do saber: eurocentrismo e ciências sociais, perspectivas latinoamericanas. Coleccion Sur-Sur, CLACSO, Ciudad Autônoma de Buenos Aires, Argentina. Setembro 2005. Available in: http://www. antropologias.org/rpc/files/downloads/2010/08/Edgardo-Lander-org-A-Colonialidade-do-Sabereurocentrismo-e-ci\% $\mathrm{C}_{3} \%$ AAncias-sociais-perspectivas-latinoamericanas-LIVRO.pdf. Access in July 31, 2017.

SVAMPA, M. 2013. "Consenso de los commodities y lenguajes de valoración en América Latina”. Revista Nueva Sociedad, 244: 30-46, marzo-abril.

TAUSSIG, M. 1980. The devil and commodity fetishism in South America. Chapel Hill: Univ. North Carolina Press.

WORLD BANK. 2016. World Bank commodity price data. Washington: World Bank.

ZHOURI, A. 2015. "From 'participation' to 'negotiation': supressing dissent in environmental conflict resolution in Brazil”. In: B. Raymond (ed.), The international handbook of political ecology. Cheltenham and Northampton: Edward Elgar Publishing. pp. 447-459.

.; BOLADOS, P.; CASTRO, E. 2016. Mineração na América do Sul: neoextrativismo e lutas territoriais. São Paulo: Ed. Annablume.

.; GENEROSO, P.; CORUJO, T. 2016. "Nas tessituras da pesquisa e da ação: narrativas de mulheres sobre água, mineração, resistência e colaboração em Minas Gerais”. In: A. Zhouri, P. Bolados, E. Castro (eds.), Mineração na América do Sul: neoextrativismo e lutas territoriais. São Paulo: Ed. Annablume. pp. 341-367. 
.; OLIVEIRA, R. 2012. "Development and environmental conflicts in Brazil:

challenges for anthropology and anthropologists”. Vibrant - Virtual Braz. Anthr., 9(1). Brasília, Jan./June.

Available in: http://www.scielo.br/scielo.php?script=sci_arttext\&pid=S1809-43412012000100007. Access in 26 July, 2017.

.; VALENCIO, N. 2014. Formas de matar, de morer e de resistir. Limites da resolução negociada de conflitos ambientais. Belo Horizonte: editora da UFMG.

Andréa Zhouri

Professor, Department of Anthropology and Archeology, Federal University of Minas Gerais - UFMG, Coordinator, Group of Environmental Studies - GESTA-UFMG, Belo Horizonte, MG, Brazil.

E-mail: azhouri@gmail.com

Acknowledgements: to the Coordenação de Aperfeiçoamento de Pessoal de Nível Superior (CAPES) for support received (Estágio Senior) during the period of conclusion of this dossier. To Antonio Carlos Souza Lima, Raquel Oliveira, and Klemens Laschefski for their comments in earlier versions of this introduction. 